\begin{abstract}
"Mircea cel Batran" Naval Academy Scientific Bulletin, Volume XX - 2017 - Issue 2
The journal is indexed in: PROQUEST / DOAJ / Crossref / EBSCOhost/ INDEX COPERNICUS/ OAJI / DRJI I

JOURNAL INDEX / I2OR / SCIENCE LIBRARY INDEX / Google Scholar / Academic Keys / ROAD Open Access I Academic Resources / Scientific Indexing Services / SCIPIO/ JIFACTOR
\end{abstract}

\title{
STUDY ON ACCOMPLISHING TASKS IN PHYSICAL EDUCATION
}

\author{
Sanda TOMA-URICHIANU ${ }^{1}$ \\ ${ }_{1}^{1}$ Professor Ph.D., Ecological University, Bucharest, Romania, sandavtoma@yahoo.com
}

\begin{abstract}
:
The purpose of this study is to create, through games of movement, the environment favorable to the biological, social and cultural-educational development of students.

The hypothesis of the study refers to the objectives of physical education through practice exercises in the form of games in general, and motion games in particular.

The proposed objectives are: physical exercises in the form of physical education are also practiced from recreational, relaxation and emulation needs; the game contributes to the development of correct physical fitness as well as the learning of motor skills; motion play becomes an excellent educational means, having a multiple and complex influence on the evolution of the child.
\end{abstract}

Keywords: objectives, development, maturation, physical education, student.

\section{Introduction.}

Man is the product of the interaction of natural and social factors in his development, each having different weights.

The need for play and movement is one of the student's basic necessities. For optimal physical and psychological development, the influence of clean air, light, and sun during motion games is of paramount importance.

All these achievements of practicing physical exercises are possible by fulfilling the tasks of school physical education. At the core of the students' physical activities are movement games, which have a positive influence on the functions of the body, contribute to the physical and intellectual development of the students, they form basic motor skills, utilities, motor skills, as well as moral traits: independence, initiative , determination, perseverance, self-control, courage, disciplined behavior, etc.

As a means of physical education, games of movement is a process with a strong formative, educates love to move in order to organize effectively and recreational leisure contributes to better health, strengthen body and increased capacity for physical work and intellectual development of pupils.

Knowing the children's pleasure for movement, play and sports, I tried to highlight, channeling the influences of the movement, the personality of the child correctly.

Hypothesis. We aim to demonstrate through this study that the movement, which is the main component of the game, ensures the concentration of children's attention towards the tasks of the physical education lesson on enhancing the basic motor skills and utilities, in accordance with the psychic and motoric particularities of the children.

2.The tasks of the physical education lesson. It is known that the tasks of the school physical education lesson are in accordance with the objectives established by the curriculum corresponding to the development stages of the pupils.

The main tasks of physical education are.

1. Strengthen health status, harmonize the level of physical development and increase the resistance of the body to the action of the pollutants in nature.

2. Development and improvement of basic motor skills and abilities, development of motor skills: speed, skill, mobility and suppleness, strength, strength, balance, and so on.

3. Forming volitional and moral qualities, competitive spirit, discipline and fair play.

4. Knowledge and development of hygiene skills, permanent practice of physical activities, recreation and fortification of the body.

5. Formation of exercise practice for the purpose of prophylaxis of sports injuries and selfcontrol and self-help.

According to Cristea, D.I. (2010) there is a link between the tasks, the general objectives and the components of the educational process in physical education in that the acquisition of these components in the educational-educational process ensures the fulfillment of the general objectives of the physical education. Correspondence between the general objectives of physical education and the components of the instructive-educational process are highlighted in the following table: 
"Mircea cel Batran" Naval Academy Scientific Bulletin, Volume XX - 2017 - Issue 2

The journal is indexed in: PROQUEST / DOAJ / Crossref / EBSCOhost/ INDEX COPERNICUS/ OAJI / DRJI I JOURNAL INDEX / I2OR / SCIENCE LIBRARY INDEX / Google Scholar / Academic Keys / ROAD Open Access I Academic Resources / Scientific Indexing Services / SCIPIOI JIFACTOR

Table 1 The general objectives of physical education and the components of the instructive-educational process (Cristea, D.I.p.19; 2010)

\begin{tabular}{|l|l|}
\hline Objectives of physical education & $\begin{array}{l}\text { The instructive-educational process } \\
\text { components }\end{array}$ \\
\hline $\begin{array}{l}\text { Maintaining within favorable health limits and } \\
\text { harmonious physical development of the body }\end{array}$ & $\begin{array}{l}\text { Morphological and functional indexes of the } \\
\text { organism }\end{array}$ \\
\hline Developing general motor skills & Motor skills, skills and driving skills \\
\hline Forming the ability to exercise independently & Driving habits, practicing performance sports \\
\hline The harmonious development of personality & $\begin{array}{l}\text { Attitudes and content elements of other aspects of } \\
\text { general education. }\end{array}$ \\
\hline
\end{tabular}

With physical activity, the student is in a position to learn new things, to experience knowledge and to improve the knowledge and skills they will be able to apply in life through development and maturation. After Epuran, M. (p. 236, 2011) "maturation is of particular interest both from the theoretical and practical point of view, as the level of maturation is taken as a reference for the various moments of growth or development"

Fig. 1 Relationships between maturity, development, learning and ambiance (Epuran, M., 1988, Epuran

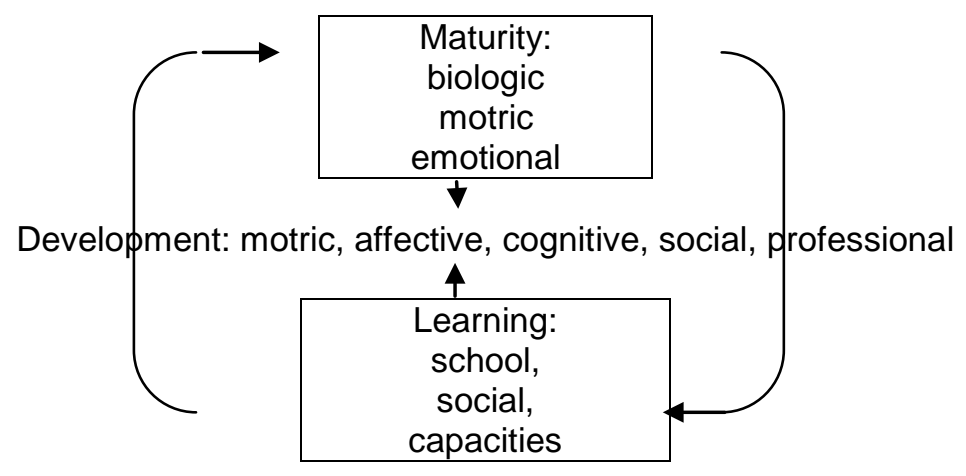

M.2011)

3. The contents of the study. The experiment was conducted at secondary school 9 on a sample of 20 subjects. The sample of children was the subject of study and research organized consists of a group of 20 children, 10 girls and 10 boys, watch during a school year. The sample of children presenting homogeneous in age and physical development. All participated in physical education in the curriculum provided in addition and stretching exercises. Before starting the experiment we talked with parents of children with doctor at the clinic, then I recorded history on the health of children, the lifestyle of the family, children wish to move. In terms of mental peculiarities I believe that all children were within the limits established for this age.Thus, they showed a high instability of attention, concentration and will nerve was reduced sufficiently developed. Therefore I tried to present activities as attractive and intuitive order capture their attention, interest in what is new and known.

\section{Stages and objectives of research}

The elaboration of this research has as main task the observation and demonstration on the basis of the obtained results of the evolution of the state of general physical training of the children in the groups and especially the consolidation of the basic motor skills by practicing motion games during the exercise of the physical education activities throughout the year school, game consolidation.

Several steps will be taken to achieve this:

a) determining the objective of the survey which is to strengthen the skills of the basic motor b) determining the tasks to be carried c) providing a sample of the work consists of two groups of children, homogeneous from the point of view of the age and the physical d) performing measurements in two stages on height and weight of children held in October initial stage of the school year 2015-2016 and final stage conducted in May for comparison. e) recording, processing and interpreting the data f) conclusions and proposals

Research methods used in the research are: observation method, with which we evaluated the effects of systematic physical education 
"Mircea cel Batran" Naval Academy Scientific Bulletin, Volume XX - 2017 - Issue 2

The journal is indexed in: PROQUEST / DOAJ / Crossref / EBSCOhost/ INDEX COPERNICUS/ OAJI / DRJI / JOURNAL INDEX I I2OR I SCIENCE LIBRARY INDEX / Google Scholar / Academic Keys I ROAD Open Access I Academic Resources / Scientific Indexing Services I SCIPIOI JIFACTOR

teaching the children physically and mentally; method is used to present practical demonstration exercises in front of the group and to show changes, collectively experimental method, carried out with the groups; data comparison method, the method of measuring the results of the test subject and used as follows: for somatic indices have measured height and weight, and to follow the development of motor skills we used classical control samples, provided the primary program.

The main objectives that we follow are: a) to develop physical fitness multilateral and harmonious; b) to help strengthen their health and the formation of a properly kept; c) to develop physical fitness and motor skills accessible to children of school age: walking, running, jumping. d) to develop interest in exercise and movement games and to form the habit of practicing them. Achieving optimum of the task is conditioned by knowledge and respect for age and individual peculiarities of pupils, the choice of their corresponding themes, applying the most appropriate means, methods, procedures for working with children.

Sample description and achievement. In initial testing at the beginning of the school year and the final test at the end we applied the same three tests, games of movement to demonstrate how to acquire skills and physical qualities, namely:

5. Data processing and interpretation. Measurements on height and weight in the initial stage and the final stage of evaluation of growth and physical development both quantitative and qualitative is an act of great responsibility of the teacher, because of the evolution of these processes can be inferred if a subject falls within the normal range, knowing that changes that occur in the body are age and gender specific. Therefore I decided to have this in mind and realize measuring height and weight of children in two stages: at the beginning and end of the school year.

Table 2. Determination of the somatic parameters in the group of girls

\begin{tabular}{|c|c|c|c|c|}
\hline \multirow{2}{*}{ Nr.crt. } & \multicolumn{2}{|c|}{ height } & \multicolumn{2}{c|}{ weight } \\
\cline { 2 - 5 } & $\begin{array}{c}\text { initial } \\
\text { testing }\end{array}$ & $\begin{array}{c}\text { final } \\
\text { testing }\end{array}$ & $\begin{array}{c}\text { initial } \\
\text { testing }\end{array}$ & $\begin{array}{c}\text { final } \\
\text { testing }\end{array}$ \\
\hline 1. & 106 & 108 & 15 & 16 \\
\hline 2. & 110 & 113 & 18.5 & 19 \\
\hline 3. & 108 & 110 & 17 & 18 \\
\hline 4. & 110 & 113 & 19.5 & 21 \\
\hline 5. & 106 & 108 & 16 & 17.5 \\
\hline 6. & 107 & 109 & 16 & $1 ., 5$ \\
\hline 7. & 109 & 112 & 18 & 19.5 \\
\hline 8. & 105 & 109 & 14.5 & 15.5 \\
\hline 9. & 108 & 110 & 17 & 18 \\
\hline 10. & 107 & 109 & 15 & 16 \\
\hline
\end{tabular}

Grafic 1

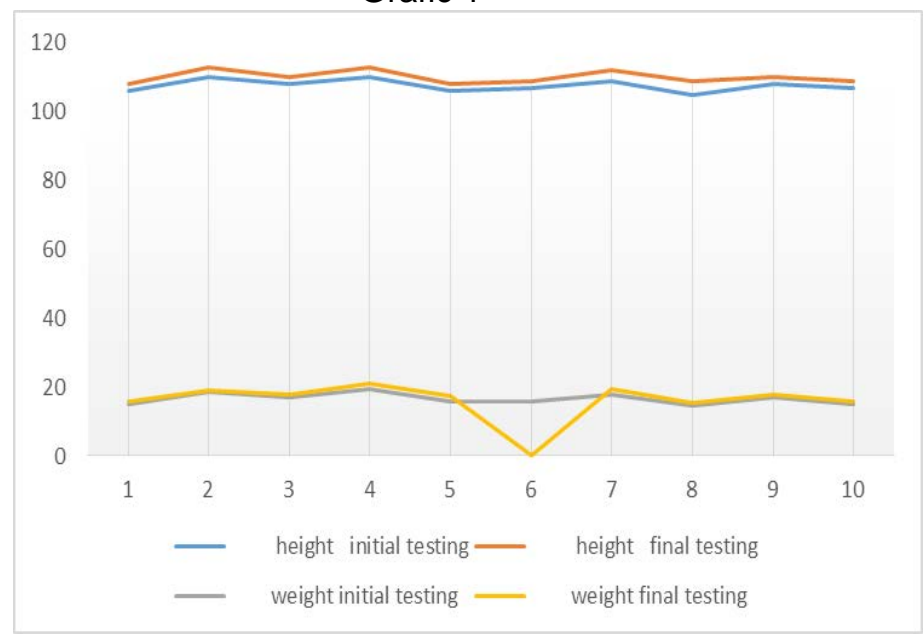

Table 3. Determining the somatic parameters in the boys group 
"Mircea cel Batran" Naval Academy Scientific Bulletin, Volume XX - 2017 - Issue 2

The journal is indexed in: PROQUEST / DOAJ / Crossref / EBSCOhost/ INDEX COPERNICUS/ OAJI / DRJI I JOURNAL INDEX I I2OR I SCIENCE LIBRARY INDEX / Google Scholar / Academic Keys I ROAD Open Access I Academic Resources / Scientific Indexing Services I SCIPIOI JIFACTOR

\begin{tabular}{|l|l|l|l|l|}
\hline \multirow{2}{*}{ Nr.crt. } & \multicolumn{2}{|c|}{ height } & \multicolumn{2}{c|}{ weight } \\
\cline { 2 - 5 } & $\begin{array}{l}\text { initial } \\
\text { testing }\end{array}$ & $\begin{array}{l}\text { final } \\
\text { testing }\end{array}$ & $\begin{array}{l}\text { initial } \\
\text { testing }\end{array}$ & $\begin{array}{l}\text { final } \\
\text { testing }\end{array}$ \\
\hline 1. & 102 & 105 & 13 & 14 \\
\hline 2. & 106 & 112 & 18 & 19.5 \\
\hline 3. & 105 & 109 & 18 & 19.5 \\
\hline 4. & 104 & 108 & 16 & 17 \\
\hline 5. & 109 & 113 & 20 & 23 \\
\hline 6. & 102 & 106 & 14 & 15.5 \\
\hline 7. & 103 & 107 & 15 & 16.5 \\
\hline 8. & 105 & 109 & 17 & 18 \\
\hline 9. & 108 & 112 & 19 & 20 \\
\hline 10. & 104 & 107 & 16 & 17 \\
\hline
\end{tabular}

Graphic 2

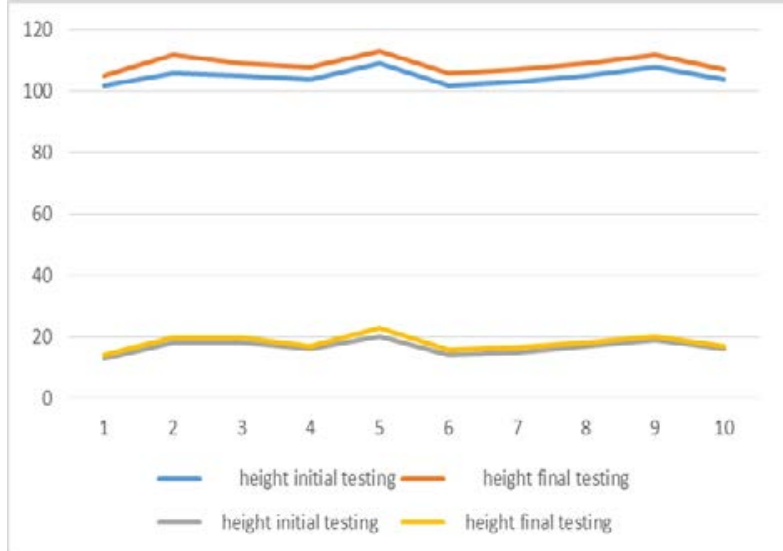

During the experiment, there were increases in physical parameters due to the influences exerted on children through the games of movement organized with them during the school year. Physical measurement data reveal an increase in height and weight in both girls and boys. Growth rates recorded following the verification of both girls and boys are highlighted in Tables 1 and 2 and in charts 1 and 2.

Results of the tests at the initial and final testing. The following tables and charts will highlight the time and mode of execution and deployment of the three samples in the games, each game comprising initial testing and final testing.

Table 4. Initial testing and final group testing of girls

\begin{tabular}{|c|c|c|c|c|c|c|}
\hline \multirow[t]{2}{*}{ No. } & \multicolumn{2}{|c|}{ Speed control } & \multicolumn{2}{|c|}{$\begin{array}{lll}\text { Long jump from } \\
\text { place }\end{array}$} & \multicolumn{2}{|l|}{ skill } \\
\hline & $\begin{array}{l}\text { initial } \\
\text { testing }\end{array}$ & $\begin{array}{l}\text { final } \\
\text { testing }\end{array}$ & $\begin{array}{l}\text { initial } \\
\text { testing }\end{array}$ & $\begin{array}{l}\text { final } \\
\text { testing }\end{array}$ & $\begin{array}{l}\text { initial } \\
\text { testing }\end{array}$ & $\begin{array}{l}\text { final } \\
\text { testing }\end{array}$ \\
\hline 1. & 5.5 & 5 & 75 & 78 & 18 & 17 \\
\hline 2. & 5.5 & 5 & 77.6 & 79 & 17.5 & 16.5 \\
\hline 3. & 5.6 & 5.1 & 77 & 80 & 18 & 17.1 \\
\hline 4. & 5.8 & 5.2 & 75 & 78 & 18 & 17 \\
\hline 5. & 5.8 & 5.2 & 76.5 & 79 & 17.5 & 16.8 \\
\hline 6. & 5.5 & 5.1 & 75.5 & 78 & 18 & 17.2 \\
\hline 7. & 5.5 & 5 & 77 & 80 & 17.5 & 16,7 \\
\hline 8. & 5.6 & 5 & 75 & 78.5 & 17 & 16 \\
\hline 9. & 5.6 & 5.2 & 76.5 & 79.5 & 17.6 & 16.2 \\
\hline 10. & 5.5 & 5 & 77 & 79 & 17 & 16 \\
\hline
\end{tabular}

Grafic 3 
"Mircea cel Batran" Naval Academy Scientific Bulletin, Volume XX - 2017 - Issue 2

The journal is indexed in: PROQUEST / DOAJ / Crossref / EBSCOhost/ INDEX COPERNICUS/ OAJI / DRJI I JOURNAL INDEX I I2OR I SCIENCE LIBRARY INDEX / Google Scholar / Academic Keys I ROAD Open Access I Academic Resources / Scientific Indexing Services I SCIPIOI JIFACTOR

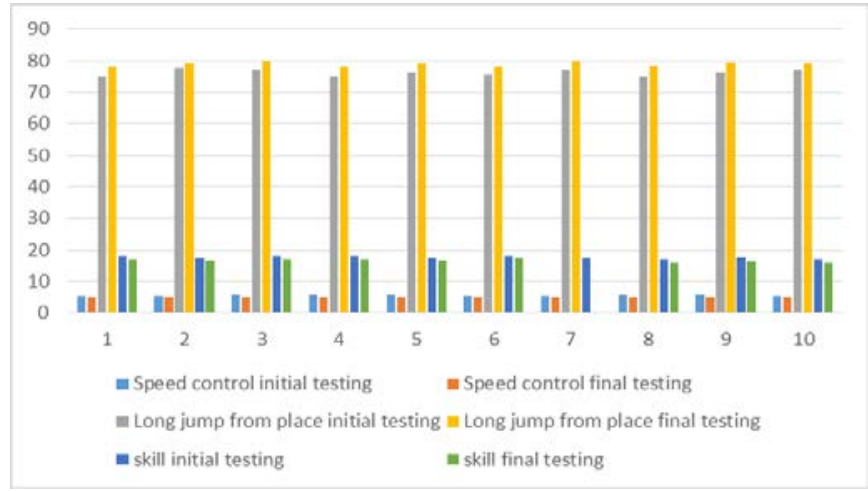

Table 5. Initial testing and final testing in the boys group

\begin{tabular}{|l|l|l|l|l|l|l|}
\hline \multirow{2}{*}{ Nr.crt. } & \multicolumn{2}{|l|}{ Speed control } & \multicolumn{2}{l}{$\begin{array}{l}\text { long jump from } \\
\text { place }\end{array}$} & \multicolumn{2}{|c|}{ skill } \\
\cline { 2 - 7 } & $\begin{array}{l}\text { initial } \\
\text { testing }\end{array}$ & $\begin{array}{l}\text { final } \\
\text { testing }\end{array}$ & $\begin{array}{l}\text { initial } \\
\text { testing }\end{array}$ & $\begin{array}{l}\text { final } \\
\text { testing }\end{array}$ & $\begin{array}{l}\text { initial } \\
\text { testing }\end{array}$ & $\begin{array}{l}\text { final } \\
\text { testing }\end{array}$ \\
\hline 1. & 6 & 5 & 76 & 79 & 19 & 17.5 \\
\hline 2. & 5.8 & 4.8 & 77 & 80.5 & 19.2 & 17.8 \\
\hline 3. & 5.5 & 5 & 77.5 & 82 & 18.8 & 17.2 \\
\hline 4. & 5.7 & 5 & 75 & 78 & 20 & 19 \\
\hline 5. & 5.8 & 4.9 & 77 & 80.5 & 18.1 & 16.5 \\
\hline 6. & 5.5 & 5 & 76 & 79 & 19 & 18.3 \\
\hline 7. & 6 & 5 & 77 & 81 & 18.5 & 17.5 \\
\hline 8. & 5.6 & 4.8 & 75.5 & 78.5 & 18 & 16.5 \\
\hline 9. & 6 & 5 & 76.5 & 80 & 19 & 17 \\
\hline 10. & 5.7 & 5 & 76.5 & 78.5 & 18 & 16.5 \\
\hline
\end{tabular}

\section{Grafic 4}

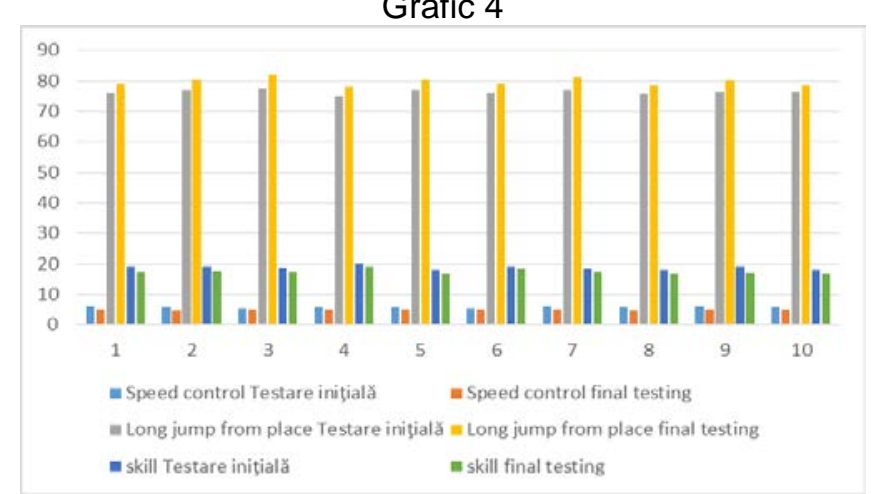

Sample results at initial and final testing:

Sample 1: Running at $15 \mathrm{~m}$ in the form of a relay. From the analysis of the obtained results compared with the ones from the initial phase we can observe the following: while the initial testing of the group of girls recorded an average of the execution time of 5.59 ', the final testing showed that the group obtained a time better, the average execution speed being lower, i.e. 5.08 '. In the boys 'group at the initial testing, an average execution time of 5.77 was obtained and an average of $4.95^{\prime}$ at the final test. There is a better execution speed compared to the results of initial boys testing.
Sample 2: Long jump on the scene as a game. From the analysis of the obtained results compared with the ones from the initial stage, we can ascertain the following: By making the average of the jumping, the group of girls in the initial testing was $76,21 \mathrm{~cm}$ and in the final test, the difference is significantly higher, the average being of $78,9 \mathrm{~cm}$. In the group of boys, the average sample was $76.4 \mathrm{~cm}$ and the final test was $79.7 \mathrm{~cm}$.

Sample 3. Game "pick flowers" - skill. From the results obtained compared with the initial phase can be found as follows: test group register with the original faces an average of 


\begin{abstract}
"Mircea cel Batran" Naval Academy Scientific Bulletin, Volume XX - 2017 - Issue 2
The journal is indexed in: PROQUEST / DOAJ / Crossref / EBSCOhost/ INDEX COPERNICUS/ OAJI / DRJI I JOURNAL INDEX I I2OR / SCIENCE LIBRARY INDEX / Google Scholar / Academic Keys / ROAD Open Access I Academic Resources / Scientific Indexing Services I SCIPIOI JIFACTOR
\end{abstract}

17.61 'and at the final test is the average time 16.65'; initial testing boys group recorded an average of 18.76 'and the final test results are much better compared to the initial test, namely an average of 17.28 '. It can be seen therefore that have made progress, both boys and girls give better results in tests end in the manner of performance and the time taken for the games offered in The experiment present what due to the hard work of the whole group, practicing systematic and methodical physical education program compliance and continuously improved using means and methods of teaching the most effective exercises and movement games that develop and strengthen various driving skills. Interpretation of results allows to demonstrate efficiency playthroughs movement throughout the day, both at school and at home. So children have learned and were able to perform accurately and in a fast-paced games, while meeting the requirements and guidelines.

\title{
CONCLUSION
}

Physical exercises as well as the motion games used will fully achieve the intended objectives if they are practiced systematically on the basis of well-planned planning, using a rigorous work system and ensuring regular control of individual evolution.

The educational value of motion games increases by their applicative character, offering the possibility to repeat the movements in various conditions, according to the specific age. Their development in the natural environment helps the child to cure the body and to strengthen health, to create a good disposition.

In the present paper I wanted to highlight the role played by motion games in the psycho-motor development of the school and to highlight its characteristics at school age in order to achieve effective teaching and consolidation. This has a special role because it ensures the calming of the body, it allows a more stable functionality, leading to a greater adaptability to the environment.

The study revealed the possibility of using some forms and means of work that would positively influence the psycho-physical development of children and to stimulate the children's desire to practice the games of movement for relaxation, recreation and improvement of motor skills, to become a reality.

Especially in the course of one school year the games were handled in a special way, but it was also diversified, contributing to its efficiency.

\section{BIBLIOGRAPHY}

[1] Cârstea, G., (1999) Physical Education. Theoretical and Methodological Fundamentals, Petru Maior Publishing, Bucharest.

[2]. Cristea D., Sabău A., Ille M., (2002) Dynamic Games, University of Oradea Publishing House.

[3]. Cristea.D.(2010)., Didactics of Physical Education, Course, University of Oradea p.42.

[4]. Dragnea, A, Bota, A.(1999) Theory of Driving Activities, Didactic and Pedagogical Publishing House Bucharest.

[5]' Dragomir, P, Scarlat, E., (2004). School Physical Education, Didactic and Pedagogical Publishing House. Bucharest.

[6] Ene-Voiculescu, V., Ene-Voiculescu, C., Abramiuc, A., Current selection procedures in the naval pentathlon, "Mircea cel Batran" Naval Academy Scientific Bulletin, Volume XX, Issue 1, pp.420-422, 2017.

[7]. Epuran, M. (2011) Motricity and psychism in body activities, vol 1, FEST Publishing, p 237.

[8]. Mesesan, V.M. (2012) Movement games - the form of physical education tasks in kindergarten, Methodical-scientific work for obtaining the didactic degree 1, Babeş - Bolyai University of Cluj - Napoca, Department for Training of Teaching Staff.

[9]. Stan, E. A. Athletic performance in synchronous swimming training programs - methodical teaching of synchronous swimming. Printech Publishing, ISBN 978-606-23-0171-2, Bucureşti, 2014.

[10]. Urichianu, B, Urichianu, A., Toma, S., Features of motion development in primary students, , Ecological University of Bucharest, Faculty of Physical Education and Sport, International Scientific Communications"Physical education and sport, healthy lifestyle boost factors"2016, ISSN 2360 -1760, Ed printech, p.5-12.

[11]. Urichianu, B, Urichianu, L; Urichianu, A., Toma, S., Consideration on the therapeutic function of the sport recreational, , Ecological University of Bucharest, Faculty of Physical Education and Sport, International Scientific Communications"Applications of kinetotherapy and sports medicine in motor activities" 2015, ISSN 2360 -2252, Ed printech, p.5-12. 